\title{
TRACHICHTHYS AUSTRALIS.
}

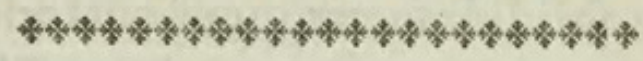

CHARACTER GENERICUS.

Caput antice rotundatum: Oculi magni: Os amplum, edentulum, defcendens.

Membrana brancbiofega radiis octo, quorum quatuor inferiores margine fcabri.

Squame fcabræ: Abdomen carinato-cataphractum,

Cernere eft in tabula veram pifcis miri magnitudinem. Corpus modice craffum, præcipue a parte antica. Caput permagnum. Os deorfum fe recludit fere perpendiculariter, linea tamen curvata; eoque claufo, frontis ambitus perfecte ovatus. Oculi prægrandes : videturque iris vivo fuiffe argentea, qualis folet plerifque pifcibus. Os caret dentibus. Lingua modica, maxillæ inferiori quafi adnata, cujus ad extremitatem fere pertingit. Branchiarum opercula partem habent fuperiorem fpina magna, fcabra, inftructam, ad bafin craffifima. Partem quoque inferiorem occupat fpina, fed minor et brevior. Operculi utriufque circumferentia paululum finuata eft, prope medium prominentiis breviffimis, fubacutis : reliquum confat e quinque vel fex lamellis in longitudinem ductis, quarum margines fcabræ more corporis. Ex radiis qui quafi octo funt in membrana branchioftega, quatuor inferiores reliquis funt craffiores, 
craffiores, lateribus fcabris. Vix alius pifcis, $f$ cataplarastos excipiamus, veftitu æque duro induitur; fquamæ enim folidifimæ et quafi cuti adnatæ, adeo arcte fibi invicem affiguntur, ut vix poffibile fit forcipe unam evellere, nifi ipfius corii aliquid fimul evellatur; qua in re fimilitudo quædam eft huic cum genere quod Baliffes dicitur. Squamarum præterea generalis formatio refpondet fere fquamis Chætodontorum; extrinfecus enim terminantur quafi fimbria parvularum et fortium fpinarum, præter alias plures in fuperficiem confperfas. Differunt paululum a fe invicem fquamæ in diverfis partibus, et prope abdomen magis dilatantur. Abdomen ipfum carinatum et quafi calaphractum eft ferie octo fquamarum fcabrarum et validarum, quarum unaquaque prominet in fpinam brevem, retro tendentem, et carinam fubtus efficientem, lateribus furfum continuatis quafi quadrantem unciæ ab utroque latere abdominis. Squamæ quoque abdominis, (ut prius notavimus) hac in parte paulo latiores quam alibi gradatim decrefcunt verfus medium corporis. A cauda utrinque linea paululum affurgit fimilis carinatæ : media enim pars fingulæ fquamæ altius prominet quam reliqua fuperficies, fquamaque ipfa hoc in loco grandiores funt quam alibi. Præter hanc vix ulla vifibilis eft linea lateralis. Pinna dorfalis quatuordecim habet radios quorum feptem pofteriores verfus apices dividuntur in molliores ramulos. Pinnæ pectorales tredecim habent radios. Ventrales feptem. Analis duodecim, plerifque apud apices mollius ramulofis. Caudam ore furcæ curvata conftat ferc e viginti quatuor radils, quorum exteriores utrinque 
utrinque validi funt feu fpinofi; reliqui quales funt in pinna anali. Pinnarum omnium, except is pectoralibus, tres primores radii validiffimi funt, fcabri, exterius tenuiter ferrati; præcipue vero ventralium. Novum genus conftituit Trachichtys Auftralis, in pifcibus thoracicis Linnæi numerandum, iis nempe quorum pinnæ ventrales fub pectoralibus fitæ funt. Cum afperrimam habeat fuperficiem, Tracbicbtbyn diximus; nomini autem triviali (donec melius phyficis innotuerit) auffralis inferviat. E veteribus omnibus Linnæanis generibus, iis fcilicet qua in Syftematis Naturæ editione duodecima continentur, nullum eft cujus ad fimilitudinem magis accedit quam ad Perca. Litora incolit Auftralafiæ. Ex variis pifcibus quos fpiritu vini conditos collegerat Dominus White coloniæ noftræ Auftraliacæ chirurgus primarius, in fpecimen incidimus unde depicta eft hæc noftra effigies. Vidimus quoque apud Dominum White iconem Trachichthyos non fane exquifitam, fatis tamen fidam ut fpeciem definiat, et colorem genuinum demonftret, læte fcilicet carneoferrugineum, qui in fpecimine affervato in fufcum exoleverat, Partis mediæ omnium pinnarum faturatior eft color quam in reliquo corpore: margines vero flavefcunt. 




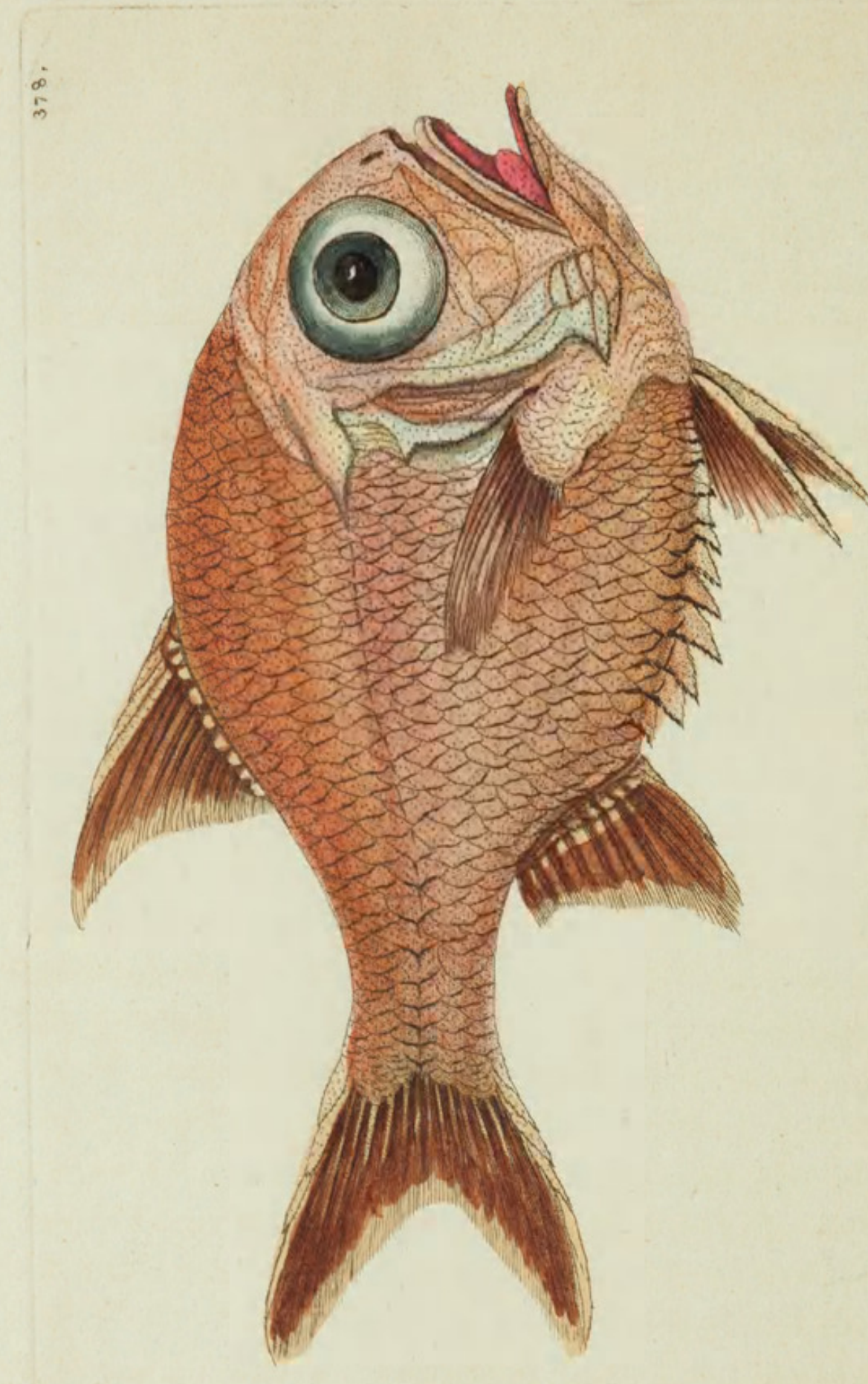

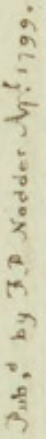




\section{SOUTHERN TRACHICHTHYS.}



\section{GENERIC CHARACTER.}

Head rounded in front: Eyes large: Mouth wide, toothlefs, defcending.

Brancbioftegous Membrane furnifhed with eight rays, of which the four lowermoft are rough on the edges.

Scales rough: Abdomen cataphracted with large carinated fcales.

This remarkable fifh is reprefented on the plate in its natural fize. The body is moderately thick, more efpecially on the fore part : the head is very large; the mouth opening downwards in an almoft perpendicular direction, but in a curved line; and, when clofed, the outline of the head or front is completely oval. The eyes are extremely large, and the iris appears to have been of a filvery hue, or as in generality of firhes. The mouth is deftitute of teeth, and the tongue, which is moderately large, is adnate, or fixed to the lower jaw, to the extremity of which it almoft reaches. The Opercula or gill-covers are furnifhed on the upper part with a large, ftrong, and rough fpine, which is very thick at its bafe: a fmaller and fhorter fpine alfo occurs at the lower 
part : the outline of each operculum is fomewhat finuated by two very thort and fubacute proceffes towards the middle; and the remainder is compofed of five or fix longitudinal rough-edged lamellæ refembling the furface of the body. The membrana brancbioftega has about eight rays, of which the four lowermoft are rough-edged, and thicker than the reft. Perhaps no fifh yet known, if we except what are called mailed or cataphracted fifh, is fo ftrongly coated as the prefent; the fcales forming a kind of proceffes, which are fo ftrongly and clofely inferted, that it is not poffible by means of a forceps to detach one from the reft, without bringing away with it a fmall portion of the corium or general integument itfelf; the $\mathrm{k}$ in in this refpect refembling in fome degree that of the genus Baliftes. Thefe fcales or proceffes, as to their general ftructure, are analogous to thofe of the Chrtodons; terminating outwardly in a fringe of fmall, ftrong fpines, befides feveral fcattered ones on the furface. They differ fomewhat in thape on different parts of the animal, and, as they approach the abdomen, become more dilated. The abdomen itfelf is carinated and cataphracted by a row of eight ftrong, rough incifures or fcales, each of which projects into a fhortifh fpine, pointing backwards, and forming a fharp keel beneath, while the fides are continued upwards near a quarter of an inch on each fide the abdomen. The fcales of the abdomen, as before obferved, are alfo fomewhat broader in this part, and gradually leffen towards the middle of the body. On each fide the tail is a flightly-prominent line, or an approach to a carinated 
appearance, owing to the middle of each fcale on that part rifing up a little above the level of the reft: the fcales alfo along this part are rather larger than elfewhere: otherwife the appearance of a lateral line is fcarce diftinct. The dorfal fin has fourteen rays, of which the feven hindermoft fubdivide towards their tips into fofter ramifications. The pectoral fins have thirteen rays: the ventral fins feven: and the anal fin twelve rays, moft of which fubdivide into fofter ramifications at the tip. The tail is ftrongly furcated, and confifts of about twenty-four rays, of which the external or fhorter ones are ftrong or fpiny; the reft of a fimilar appearance to thofe of the anal fin. The three firft rays of all the fins, except the pectoral ones, are very ftrong, rough, and finely ferrated outwards, but more particularly thofe of the ventral fins.

This fifh, which conititutes a new genus, belongs to the Linnæan divifion of Thoracici, or fuch as have the ventral fins fituated beneath the pectoral ones. From its uncommonly rough furface I have given it the generic name of Tracbicbthys, and as a trivial name, at leaft till we are better acquainted with its natural hiftory, it may be fuffirient to diftinguifh it by the title of Aufralis. Of all the old Linnzan genera, or thofe contained in the twelfth edition of the Syftema Naturx, it feems to approach the neareft to that of Perca. The Tracbicbtbys Auftralis is a native of the coafts of New Holland, and the fpecimen from which the prefent engraving was taken occurred amongft feveral other fifhes preferved in fpirits in the collection of Mr. White, chief Surgeon to the 
Englifh fettlement in thofe regions. Among fome drawings in Mr. White's poffeffion I have alfo obferved a reprefentation of this fifh, which though not executed with minute precifion as to fome particulars, ferves at leaft to identify the animal, as well as to fhew the natural color, which is a bright pink-ferruginous or fair reddifh-brown; whereas in the preferved fpecimen the color is faded into a dull brown. The middle part of all the fins is of a deeper color than the reft of the animal, and the edges are lighter, or of a yellowih tinge. 


\section{$2 \mathrm{BHL}$ Biodiversity Heritage Library}

Shaw, George. 1799. "The Southern Trachichthys, Trachichthys australis [PI. 378]." The Naturalist's Miscellany 10(CXVI), https://doi.org/10.5962/p.304560.

View This Item Online: https://www.biodiversitylibrary.org/item/276641

DOI: https://doi.org/10.5962/p.304560

Permalink: https://www.biodiversitylibrary.org/partpdf/304560

\section{Holding Institution}

Museums Victoria

\section{Sponsored by}

Atlas of Living Australia

\section{Copyright \& Reuse}

Copyright Status: Public domain. The BHL considers that this work is no longer under copyright protection.

This document was created from content at the Biodiversity Heritage Library, the world's largest open access digital library for biodiversity literature and archives. Visit BHL at https://www.biodiversitylibrary.org. 